\title{
Copolymerization of Epoxycyclohexane and Carbon Dioxide with Metal Amides
}

\author{
Yasuhiko YosHIDA and Shohei INOUE \\ Department of Synthetic Chemistry, Faculty of Engineering, \\ The University of Tokyo, Bunkyo-ku, Tokyo 113, Japan.
}

(Received May 14, 1980)

\begin{abstract}
KEY WORDS Carbon Dioxide / Metal Amide / Epoxycyclohexane / Copolymerization / Ethylzinc Diphenylamide / Diethylaluminium diethylamide /
\end{abstract}

As we have already reported, carbon dioxide copolymerizes with epoxide by using an organometallic system as the catalyst. ${ }^{1,2}$ Among the catalyst systems so far examined, the most effective one found was a reaction mixture of diethylzinc and an equimolar amount of a compound having two active hydrogens, such as water and primary amines. ${ }^{2}$ On the other hand, a reaction mixture of diethylzinc and a compound having but one active hydrogen, such as methanol and secondary amines, did not function as an effective catalyst in the copolymerization of carbon dioxide and epoxypropane. ${ }^{2,3}$

Certain metal dialkylamides however are known to react with carbon dioxide to give metal carbamates. For example, ethylzinc diphenylamide, formed by a reaction of diethylzinc with diphenylamine, readily reacts with carbon dioxide. ${ }^{4}$ Tetrakis(dimethylamido)titanium is also very reactive towards carbon dioxide. ${ }^{5}$ We found that epoxycyclohexane reacted with titanium carbamate to give quantitative yields of the carbamic esters of 1,2-diol, corresponding to the epoxide. ${ }^{6}$

This prompted us to examine the catalytic activity of various metal amides including zinc, aluminium, titanium and tungsten, for the copolymerization of carbon dioxide and epoxycyclohexane.

\section{EXPERIMENTAL}

\section{Preparation of Copolymer}

Copolymerization of carbon dioxide and epoxide by metal amide was carried out in an autoclave, as reported previously. ${ }^{1,2}$ The reaction mixture was diluted with benzene, washed with dilute hydrochloric acid, then with water, and subjected to freeze drying, to give the product, a mixture of copolymer, cyclic carbonate and carbamic ester, depending on the reaction conditions. The copolymer was obtained as a methanol-insoluble part by pouring the benzene solution of the product into a large amount of methanol.

\section{Characterization of Copolymer}

The content of the oxycarbonyl unit $\left(f_{\mathrm{CO}_{2}}\right)$ of the copolymer, a poly(carbonate-ether), was determined by the ratios of the absorptions due to the methine protons adjacent to the oxycarbonyl linkage at $4.8 \mathrm{ppm}$ and due to the ether linkage at $3.5 \mathrm{ppm}$ in ${ }^{1} \mathrm{H}$ NMR of the copolymer. ${ }^{7}$

\section{RESULTS AND DISCUSSION}

Similar to $\mathrm{Ti}\left(\mathrm{NMe}_{2}\right)_{4}$, transition metal amides such as $\mathrm{CpTi}\left(\mathrm{NMe}_{2}\right)_{3},{ }^{5}\left[\mathrm{Ti}\left(\mathrm{NMe}_{2}\right)_{3}\right]_{2},{ }^{8}$ and tungsten amide $\left(\mathrm{W}_{2}\left(\mathrm{NMe}_{2}\right)_{6}+\mathrm{W}\left(\mathrm{NMe}_{2}\right)_{6}\right),{ }^{9}$ also reacted with carbon dioxide and epoxycyclohexane to yield 2-hydroxycyclohexyl dimethylcarbamate quantitatively, but the copolymer of carbon dioxide and epoxycyclohexane was not formed (eq 1).

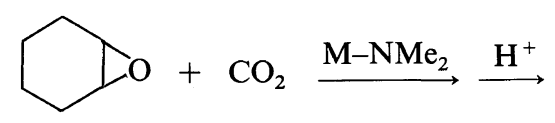




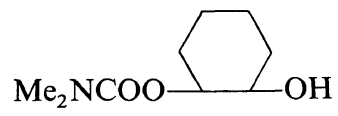

\section{$\mathrm{M}: \mathrm{Ti}, \mathrm{W}$}

The reaction mixture of diethylzinc with an equimolar amount of diethylamine was not active for the copolymerization of carbon dioxide and epoxycyclohexane, but gave the carbamic ester in a trace amount. The reaction of carbon dioxide and epoxycyclohexane with $\mathrm{EtZnNPh}_{2}{ }^{4}$ however gave a copolymer having a fairly high content of oxycarbonyl unit $(\mathrm{O}-(\mathrm{C}=\mathrm{O})-)\left(f_{\mathrm{CO}_{2}}=38 \%\right)$, though the copolymer was not completely alternating (Table I). $\mathrm{Et}_{2} \mathrm{AlNEt}_{2}{ }^{10}$ afforded a copolymer having a lower content of oxycarbonyl unit $\left(f_{\mathrm{CO}_{2}}=25 \%\right)$ and a lower molecular weight. The copolymer yield obtained with $\mathrm{Et}_{2} \mathrm{AlNEt}_{2}$ or $\mathrm{EtZnNPh}_{2}$ was high for examples of carbon dioxide-epoxide copolymerization reported so far. ${ }^{2}$

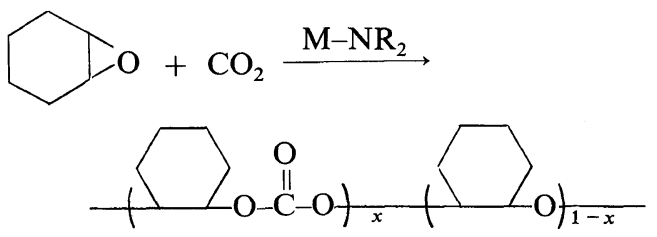

$\mathrm{M}: \mathrm{Al}, \mathrm{Zn}$

As shown in Tabel II, the copolymerization of carbon dioxide and epoxycyclohexane with $\mathrm{Et}_{2} \mathrm{AlNEt}_{2}$ was considerably affected by the nature of solvent. In more basic solvents, the yield of copolymer was less, but the content of the oxycarbonyl unit $\left(f_{\mathrm{CO}_{2}}\right)$ of the copolymers was similar regardless of the solvent (Runs 1-4). These results indicate that the solvent competes with epoxycyclohexane or carbon dioxide to coordinate with the aluminium atom of the catalyst. When copolymerization was conducted with $\mathrm{Et}_{2} \mathrm{AlNEt}_{2}$ as the concentration of $\mathrm{Et}_{2} \mathrm{AlNEt}_{2}$ for epoxycyclohexane was increased from $1.2 \mathrm{~mol} \%$ to $6 \mathrm{~mol} \%$ (Runs 5,1 , and 6$)$, the content of oxycarbonyl unit $\left(f_{\mathrm{CO}_{2}}\right)$ increased from $21 \%$ to $37 \%{ }^{*}$ The copolymer obtained under higher carbon dioxide pressure had a higher content of oxycarbonyl unit, but in a lower yield (Runs 5 and 7).

Organoaluminium compounds $\left(\mathrm{Et}_{3} \mathrm{Al}\right.$, $\mathrm{Et}_{2} \mathrm{AlNEt}_{2}$ and $\mathrm{Et}_{2} \mathrm{AlOEt}$ ) were good catalysts for carrying out the copolymerization of carbon dioxide and epoxycyclohexane giving a copolymer having a content of oxycarbonyl unit similar to each other $\left(f_{\mathrm{CO}_{2}}=21-27 \%\right)$, but aluminium isopropoxide $\left(\mathrm{Al}\left(\mathrm{OCHMe}_{2}\right)_{3}\right)$, aluminium stearate $\left(\left(\mathrm{C}_{17} \mathrm{H}_{35} \mathrm{COO}\right)_{3} \mathrm{Al}\right)$ and aluminium hydroxide $\left(\mathrm{Al}(\mathrm{OH})_{3}\right)^{* *}$ were not active in bringing about copolymerization. It is known that $\mathrm{Et}_{3} \mathrm{Al}$, $\mathrm{Et}_{2} \mathrm{AlNEt}_{2}$ and $\mathrm{Et}_{2} \mathrm{AlOEt}$ are dimeric, ${ }^{11}$ but

* Although the reaction temperature of run 6 in Table II was different from those of other runs, the reaction temperature in the range from 30 to $80^{\circ} \mathrm{C}$ was found not to affect the content of oxycarbonyl unit of the copolymer, when the copolymerization of carbon dioxide and epoxycyclohexane was carried out with $\mathrm{Et}_{2} \mathrm{AlNEt}_{2}$.

** These aluminium compounds were commercially obtained and used without further purification.

Table I. Compolymerization of carbon dioxide and epoxycyclohexane with metal amides ${ }^{\mathrm{a}}$

\begin{tabular}{|c|c|c|c|c|c|c|}
\hline \multirow{3}{*}{ Run } & \multirow{3}{*}{ Catalyst } & \multirow{3}{*}{$\mathrm{mol} \% \mathrm{~b}$} & \multirow{3}{*}{$\frac{\text { Time }}{\mathrm{h}}$} & \multicolumn{3}{|c|}{ Copolymer } \\
\hline & & & & Yield $^{c}$ & $f_{\mathrm{CO}_{2}}{ }^{\mathrm{d}}$ & {$[\eta]^{\mathrm{e}} \times 10^{2}$} \\
\hline & & & & $\mathrm{g}(\%)$ & $\%$ & $\mathrm{~cm}^{3} \mathrm{~g}^{-1}$ \\
\hline 1 & $\mathrm{EtZnNPh}_{2}$ & 3.5 & 16 & $28.6(57)$ & 38 & 0.24 \\
\hline 2 & $\mathrm{Et}_{2} \mathrm{AlNEt}_{2}$ & 1.4 & 18 & $24.8(55)$ & 25 & $0.05^{\mathrm{f}}$ \\
\hline
\end{tabular}

a Epoxycyclohexane, $40 \mathrm{~g} ; \mathrm{CO}_{2}, 50 \mathrm{~atm}$ (SI-unit; $1 \mathrm{~atm}=101.325 \mathrm{~Pa}$ ); temp, $80^{\circ} \mathrm{C}$.

b For epoxide.

c Methanol-insoluble part. Based on epoxycyclohexane.

d Content of oxycarbonyl unit in the copolymer.

e Measured at $30^{\circ} \mathrm{C}$ in benzene solution.

f $M_{n}, 1700$ (measured by cryoscopy in benzene). 
Compolymn of Epoxycyclohexane and Carbon Dioxide with Metal Amides

Table II. Copolymerization of carbon dioxide and epoxycyclohexane with $\mathrm{Et}_{2} \mathrm{AlNEt}_{2}{ }^{\mathrm{a}}$

\begin{tabular}{|c|c|c|c|c|c|c|c|c|}
\hline \multirow{3}{*}{ Run } & \multirow{3}{*}{$\frac{\mathrm{Et}_{2} \mathrm{AlNEt}_{2}}{\mathrm{~mol} \% \mathrm{~b}}$} & \multirow{3}{*}{ Solvent } & \multirow{3}{*}{$\frac{\mathrm{CO}_{2}}{\mathrm{~atm}}$} & \multirow{3}{*}{$\frac{\text { Temp }}{{ }^{\circ} \mathrm{C}}$} & \multicolumn{4}{|c|}{ Copolymer } \\
\hline & & & & & \multirow[t]{2}{*}{ Total } & \multicolumn{3}{|c|}{$\mathrm{MeOH}$-insol } \\
\hline & & & & & & Yield & $f_{\mathrm{CO}_{2}}$ & $M_{n}$ \\
\hline 1 & 3.0 & Benzene & 30 & 80 & $12.4 \mathrm{~g}$ & $8.5 \mathrm{~g}(70 \%)^{\mathrm{d}}$ & $34 \%$ & $3.0 \times 10^{3}$ \\
\hline 2 & 3.0 & Dioxane & 30 & 80 & 6.8 & $1.3 \quad(11 \%)$ & 32 & 2.1 \\
\hline 3 & 3.0 & Pyridine & 30 & 80 & 4.2 & $(-)$ & - & - \\
\hline 4 & 3.0 & Hexane & 30 & 80 & - & $(41 \%)$ & 32 & 2.0 \\
\hline 5 & 1.2 & Benzene & 30 & 80 & 7.0 & $(56 \%)$ & 21 & 3.3 \\
\hline $6^{\mathrm{e}}$ & 6.0 & Benzene & 30 & 30 & 10.2 & $(38 \%)$ & 37 & 2.7 \\
\hline 7 & 1.2 & Benzene & 105 & 35 & 1.5 & $(0.1 \%)$ & 40 & - \\
\hline
\end{tabular}

a Epoxycyclohexane, $9.7 \mathrm{~g}$; time, 40 hours; solvent, $25 \mathrm{ml}$.

b For epoxycyclohexane.

c Methanol-soluble parts are the copolymers with similar $f_{\mathrm{CO}_{2}}$ to the insoluble part, as evidenced by the infrared spectra.

d Based on epoxycyclohexane.

e Time, 70 hours.

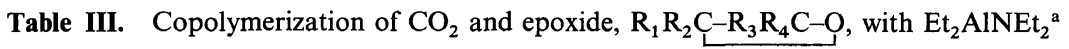

\begin{tabular}{|c|c|c|c|c|c|c|c|c|c|c|c|}
\hline \multirow{4}{*}{ Run } & & & & & \multirow{4}{*}{$\frac{\mathrm{Et}_{2} \mathrm{AlNEt}_{2}}{\mathrm{~mol} \% \%^{\mathrm{c}}}$} & \multirow{4}{*}{$\frac{\text { Time }}{\mathrm{h}}$} & \multicolumn{5}{|c|}{ Products } \\
\hline & \multicolumn{4}{|c|}{ Epoxide } & & & \multirow{3}{*}{$\frac{\text { Total }}{\mathrm{g}}$} & \multicolumn{2}{|c|}{ Copolymer $^{\mathrm{d}}$} & \multirow{3}{*}{$\begin{array}{c}\text { Polyether } \\
\text { g }\end{array}$} & \multirow{3}{*}{$\begin{array}{c}\begin{array}{c}\text { Cyclic } \\
\text { carbonate }\end{array} \\
\mathrm{g}\end{array}$} \\
\hline & \multirow[t]{2}{*}{$\mathrm{R}_{1}$} & \multirow[t]{2}{*}{$\mathrm{R}_{2}$} & \multirow[t]{2}{*}{$\mathrm{R}_{3}$} & \multirow[t]{2}{*}{$\mathrm{R}_{4}(\mathrm{~g})$} & & & & \multicolumn{2}{|l|}{ Yield } & & \\
\hline & & & & & & & & $\mathrm{g}$ & $\%$ & & \\
\hline 1 & $\mathrm{Me}$ & $\mathbf{H}$ & $\mathbf{H}$ & H (17) & 2.0 & 50 & 0.39 & 0 & - & 0 & 0.39 \\
\hline $2^{b}$ & Et & $\mathrm{H}$ & $\mathbf{H}$ & H (29) & 0.7 & 240 & 3.6 & 0 & - & 3.6 & 0 \\
\hline 3 & $\mathrm{Me}$ & $\mathrm{Me}$ & $\mathrm{H}$ & H (7.2) & 1.2 & 70 & 0 & - & - & - & - \\
\hline 4 cis & $\mathrm{Me}$ & $\mathrm{H}$ & $\mathrm{Me}$ & H (7.2) & 3.0 & 280 & 7.2 & 0 & 0 & 0 & $5.4^{\mathrm{e}}$ \\
\hline 5 trans & $\mathrm{Me}$ & $\mathrm{H}$ & $\mathrm{Me}$ & $\mathrm{H} \quad(7.2)$ & 3.0 & 520 & 0.07 & 0 & - & 0.07 & 0 \\
\hline 6 & $\mathrm{Ph}$ & $\mathrm{H}$ & $\mathbf{H}$ & $\mathrm{H}$ (24) & 1.5 & 140 & - & 0.09 & 15 & 0 & 0 \\
\hline 7 & $\mathrm{H}$ & $(-\mathrm{Cr}$ & $\left.I_{2}\right)_{3}$ & $\mathrm{H}$ (8.4) & 3.0 & 160 & $1.6^{\mathrm{f}}$ & 0.03 & 45 & 0 & 0 \\
\hline 8 & $\mathrm{H}$ & $+\mathrm{CH}$ & $\left.I_{2}\right)_{4}$ & H (9.7) & 1.2 & 70 & $5.0^{\mathrm{f}}$ & 3.4 & 25 & 0 & 0 \\
\hline
\end{tabular}

a In benzene, $40 \mathrm{ml}$; temp, $35^{\circ} \mathrm{C} ; \mathrm{CO}_{2}, 30 \mathrm{~atm}$.

b Without benzene.

c For epoxide.

d Methanol-insoluble part.

e Threo-4,5-dimethyl-1,3-dioxolan-2-one. (trans-2,3-butylene carbonate) was isolated by the distillation (yield, 40\%).

${ }^{\mathrm{f}}$ Methanol-soluble parts are the copolymers with similar $f_{\mathrm{CO}_{2}}$ to the insoluble part.

$\mathrm{Al}\left(\mathrm{OCHMe}_{2}\right)_{3}$ is tetrameric in benzene. ${ }^{12}$ The results of copolymerization with various aluminium compounds indicate that the catalytic activity for copolymerization is strongly dependent on the degree and strength of the association of the aluminium compounds. It is considered that this strong association of the aluminium compounds hinders the coordination of epoxide or carbon dioxide with the aluminium atom.

The copolymerization of carbon dioxide and 
various epoxides with $\mathrm{Et}_{2} \mathrm{AlNEt}_{2}$ was examined, as shown in Table III. Among the epoxides examined, only epoxycyclohexane gave the copolymer in good yield (Run 8). Phenylepoxyethane and epoxycyclopentane gave copolymers in low yield (Runs 6 and 7). cis-2,3-Epoxybutane gave threo-4,5-dimethyl-1,3dioxolan-2-one (cyclic carbonate of trans-form) in good yield, while trans-2,3-epoxybutane gave neither the copolymer nor the cyclic carbonate.

\section{CONCLUSION}

It was found that transition-metal amides ( $\mathrm{Ti}$ and W) reacted with carbon dioxide and epoxycyclohexane, to give the carbamic ester quantitatively.

Zinc and aluminium amides were found to be active catalysts for the copolymerization of carbon dioxide and epoxycyclohexane.

\section{REFERENCES}

1. S. Inoue, H. Koinuma, and T. Tsuruta, J. Polym.
Sci., B, 7, 287 (1969); Makromol. Chem., 130, 210 (1969).

2. Reviews: S. Inoue, Chemtech., 6, 588 (1976); S. Inoue, Prog. Polym. Sci. Jpn., 8, 1 (1975).

3. S. Inoue, M. Kobayashi, H. Koinuma, and T. Tsuruta, Makromol. Chem., 155, 61 (1972).

4. J. G. Noltes, Rec. Trav. Chim., 80, 126 (1965).

5. G. Chandra and M. F. Lappert, Inorg. Nucl. Chem. Lett., 1, 83 (1965).

6. Y. Yoshida and S. Inoue, Bull. Chem. Soc. Jpn., 51, 559 (1978).

7. H. Koinuma and H. Hirai, Makromol. Chem., 178, 1283 (1977).

8. M. H. Chisholm, F. A. Cotton, M. W. Extine, and B. R. Stults, J. Am. Chem. Soc., 98, 4477 (1976).

9. M. H. Chisholm and M. W. Extine, J. Am. Chem. Soc., 99, 782 and 792 (1977).

10. W. P. Neuman, Ann. Chem., 667, 1 (1963); S. Inoue and Y. Yokoo, Bull. Chem. Soc. Jpn., 45, 3651 (1972).

11. E. G. Hoffmann, Ann. Chem., 629, 104 (1960).

12. V. J. Shriner, D. Whittaker, and V. P. Fernandez, $J$. Am. Chem. Soc., 85, 2318 (1963). 